\title{
The Effect of Sodium Chloride and NADH on the Growth of Six Strains of Haemophilus Species Pathogenic to Chickens
}

\author{
By R. B. RIMLER \\ College of Veterinary Medicine, Poultry Disease Research Center, \\ Department of Avian Medicine, University of Georgia, Athens, Georgia 3060I, U.S.A. \\ E. B. SHOTTS, JR, AND J. BROWN \\ Department of Medical Microbiology, University of Georgia \\ AND R. B. DAVIS \\ College of Veterinary Medicine, Poultry Disease Research Center, \\ Department of Avian Medicine, University of Georgia
}

(Received 31 August 1976)

\section{SUMMARY}

Six strains of Haemophilus species, pathogenic to chickens, required $\mathrm{I} \cdot \mathrm{O}$ to $\mathrm{I} \cdot 5 \%(\mathrm{w} / \mathrm{v}) \mathrm{NaCl}$ for optimum growth. The requirement was for $\mathrm{Na}^{+}$rather than $\mathrm{NaCl}$. A sodium salt buffer influenced the optimum $\mathrm{NaCl}$ requirement and enhanced growth. Each strain required a different concentration of NADH for an optimum rate of growth.

\section{INTRODUCTION}

Evidence has been presented that Haemophilus gallinarum utilizes NAD (V factor) rather than both $\mathrm{X}$ factor (haemin) and V factor as a supplement for growth (Biberstein, Mini \& Gills, 1963; Page, 1962). This finding was contrary to earlier descriptions by Schalm \& Beach (I936) and Delaplane, Erwin \& Stuart (I938), who reported requirements for both $\mathrm{X}$ and $\mathrm{V}$ factors. Because of discrepancies between these nutritional studies, Biberstein \& White (I969) proposed a classification for two distinct species of Haemophilus which cause infectious coryza of chickens. The proposed species were $H$. gallinarum and H. paragallinarum.

According to this classification, $H$. gallinarum requires both $\mathrm{X}$ and $\mathrm{V}$ factors, and approximately $\mathrm{I} \cdot 0 \% \mathrm{NaCl}$ for optimum growth. In contrast, $H$. paragallinarum requires only $\mathrm{V}$ factor with not more than $0.5 \% \mathrm{NaCl}$. Both species require an increased $\mathrm{CO}_{2}$ tension with the addition of serum to the medium (Zinnemann \& Biberstein, I975).

Strains of the organism originally described as $H$. gallinarum (Delaplane, Erwin \& Stuart, 1934; Elliot \& Lewis, 1934; Nelson, 1932; Schalm \& Beach, 1936), and reported to require both $\mathrm{X}$ and $\mathrm{V}$ factors, have been lost and are not available for study. The requirement of $\mathrm{X}$ factor for these strains is questionable.

Considering the possible existence of two distinct species of Haemophilus which cause an infectious coryza of chickens, the current descriptions of differential characteristics may be accurate only with respect to the $\mathrm{X}$ and $\mathrm{V}$ factor requirement. Only the original $H$. gallinarum strains were studied with regard to optimum $\mathrm{NaCl}$ concentration and requirement (Delaplane et al., I938; Gregory, I944). Although a requirement for $\mathrm{NaCl}$ was established, differences in optimum concentrations were observed. Extension of these studies raised doubt as to a need for serum for the growth of these strains (Gregory, 1944). 
The objective of our study was to define the $\mathrm{NaCl}$ and $\mathrm{NADH}$ requirements of six strains of haemophilic Gram-negative bacteria which do not require the $\mathrm{X}$ factor, and which cause infectious coryza of chickens.

\section{METHODS}

Bacterial cultures. The six strains described by Rimler et al. (1976) were used, of which five were designated $H$. gallinarum at acquisition.

Slide agglutination using type-specific $H$. gallinarum antiserum acquired from $\mathrm{Dr}$ L. A. Page, National Animal Disease Center, Ames, Iowa, U.S.A., demonstrated that strains Modesto, w and 17756 were serotype A. Strain 0222 was serotype B and strain $\mathrm{z}$ was serotype C. Strain $\mathrm{G}$ reacted to all the typing sera.

Initially all strains were pathogenic for chickens, but laboratory manipulation has probably rendered strains 0222 and $z$ avirulent.

Media. The maintenance medium (MM), the method used for maintenance of cultures, preparation of inocula, and the solution (WS) used for washing the organisms and adjustment of inocula density were as described by Rimler et al. (1976).

The test medium base (TMB) contained the same ingredients as WS. All test media were adjusted to $\mathrm{pH} 7.5$ with $\mathrm{I} \mathrm{M}-\mathrm{NaOH}$, dispensed in $5 \mathrm{ml}$ portions in $\mathrm{I} 3 \times 100 \mathrm{~mm}$ optically matched screw cap tubes and autoclaved at $\mathrm{I} \cdot 05 \mathrm{~N} \mathrm{~cm}^{-2}$ for 15 min unless stated otherwise. NADH (Calbiochem) was sterilized by filtration through $0.22 \mu \mathrm{m}$ Millipore filter units and added aseptically when required.

Culture conditions. All broth cultures (screw caps loosened) were incubated for 24 and $48 \mathrm{~h}$ at $37^{\circ} \mathrm{C}$ under $\mathrm{CO}_{2}$ tension as previously described (Rimler et al., 1976).

Standardization of inocula and measurement of growth. Organisms grown in $20 \mathrm{ml} \mathrm{MM}$ for $24 \mathrm{~h}$ were recovered by centrifuging, washed three times in equal volumes of WS, and resuspended to give a light transmittance (T) of $90 \%$. An inoculum of $0.05 \mathrm{ml}$ per tube of this suspension was used to seed all test media. Inocula were standardized and growth was measured turbidimetrically in the $13 \times 100 \mathrm{~mm}$ tubes at $660 \mathrm{~nm}$. TMB served as the standard for adjustment of inocula; uninoculated control tubes served as standards for measurements of growth. Measurements were made after 24 and $48 \mathrm{~h}$ incubation. All experiments were repeated three times.

Effect of $\mathrm{NaCl}$ and other salts on growth. The effect of $\mathrm{NaCl}$ from o to $3.0 \%(\mathrm{w} / \mathrm{v})$ was tested in both TMB and TMB prepared in $0.02 \mathrm{M}$-phosphate buffer $\mathrm{pH} 7.5$. Other salts examined were $\mathrm{NaH}_{2} \mathrm{PO}_{4}, \mathrm{KH}_{2} \mathrm{PO}_{4}$ and $\mathrm{MgSO}_{4}$ at 0.085 and $0.17 \mathrm{M}$. Where necessary the $\mathrm{pH}$ was adjusted to 7.5 with I $\mathrm{M}-\mathrm{NaOH}$. All media contained $50 \mu \mathrm{g} \mathrm{NADH} \mathrm{ml}{ }^{-1}$.

Optimum NADH requirement. This requirement was examined in TMB prepared in $0.02 \mathrm{M}$-phosphate buffer $\mathrm{pH} 7.5$ and containing $\mathrm{I} \%(\mathrm{w} / \mathrm{v}) \mathrm{NaCl}$. NADH was added to give a twofold incremental sequence in final concentration covering the range $\mathrm{I} \cdot 56$ to $100 \mu \mathrm{g} \mathrm{ml}^{-1}$. Medium without NADH was also included.

Statistical analysis. The effect of $\mathrm{NaCl}$ on the growth of individual strains after $48 \mathrm{~h}$ incubation was examined in an initial analysis of variance using Duncan's New Multiple Range Test (Steel \& Torrie, I960). 'No growth' was interpreted as $100 \% \mathrm{~T}$ in two replicates and $99.5 \% \mathrm{~T}$ or greater in the third. A factorial analysis was done for the $48 \mathrm{~h}$ growth period because the results were more definitive. The factors considered were: (i) strain; (ii) $\mathrm{NaCl}$ medium (with or without buffer) and (iii) percentage $\mathrm{NaCl}$ (with or without buffer) over the 0.5 to $\mathrm{I} \cdot 5 \%$ range. A final two-factor analysis of variance was calculated for both incubation periods to make single degree of freedom comparisons (orthogonal).

The data for NADH requirement were analysed for each incubation period using an 


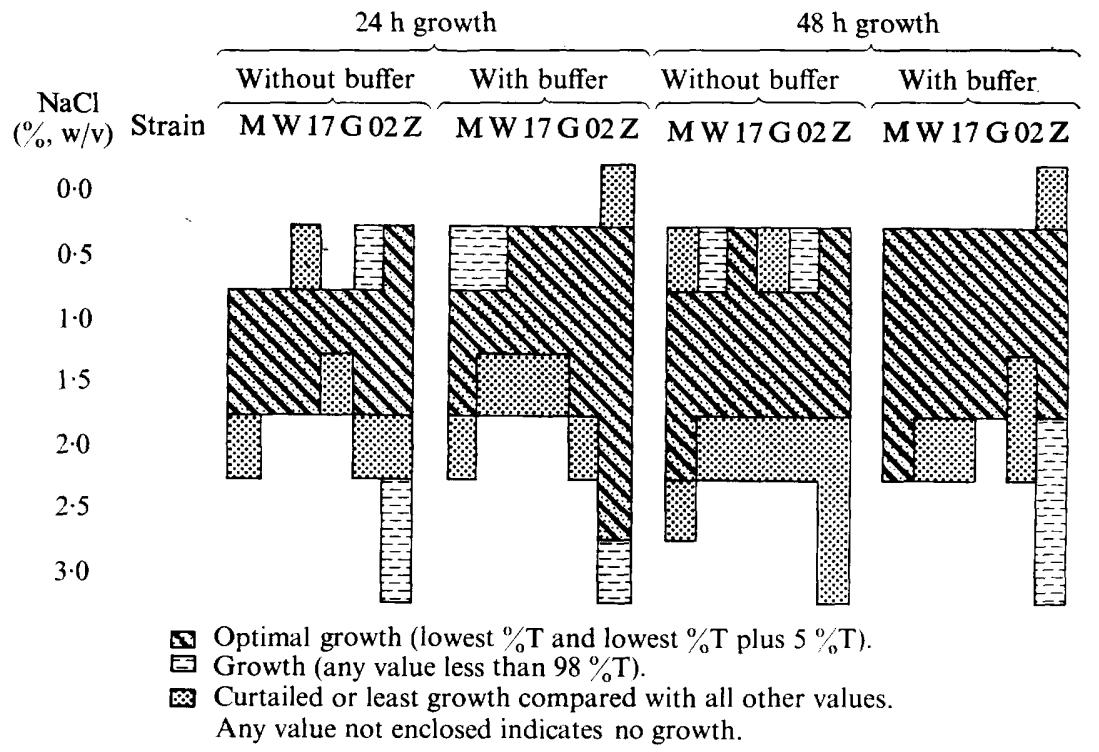

Fig. I. Growth of six strains (Modesto, w, 17756, G, 0222, z) of Haemophilus species in TMB with and without buffer and $\mathrm{NaCl}$.

Table I. Orthogonal comparisons* of the mean $\dagger$ light transmittance of six strains of Haemophilus species grown in TMB, with and without buffer, and containing different concentrations of $\mathrm{NaCl}$

\begin{tabular}{|c|c|c|c|c|c|c|c|c|c|c|c|c|}
\hline \multirow[b]{3}{*}{ Strain } & \multicolumn{6}{|c|}{ Growth at $24 \mathrm{~h}(\% \mathrm{~T})$} & \multicolumn{6}{|c|}{ Growth at $48 \mathrm{~h}(\% \mathrm{~T})$} \\
\hline & \multicolumn{3}{|c|}{$\begin{array}{l}\mathrm{NaCl}(\%, w / v) \\
\text { alone }\end{array}$} & \multicolumn{3}{|c|}{$\begin{array}{c}\mathrm{NaCl}(\%, w / v) \\
\text { with buffer }\end{array}$} & \multicolumn{3}{|c|}{$\begin{array}{c}\mathrm{NaCl}(\%, \mathrm{w} / \mathrm{v}) \\
\text { alone }\end{array}$} & \multicolumn{3}{|c|}{$\begin{array}{c}\mathrm{NaCl}(\%, w / v) \\
\text { with buffer }\end{array}$} \\
\hline & $\begin{array}{l}0.5 \\
\mathrm{~A}\end{array}$ & $\begin{array}{c}\mathrm{I} \cdot \mathrm{O} \\
\mathrm{B}\end{array}$ & $\stackrel{I \cdot 5}{C}$ & $\begin{array}{l}0.5 \\
D\end{array}$ & $\begin{array}{l}\mathrm{I} \cdot \mathrm{O} \\
\mathrm{E}\end{array}$ & $\begin{array}{l}\mathrm{I} \cdot 5 \\
\mathrm{~F}\end{array}$ & $\stackrel{0.5}{A}$ & $\begin{array}{c}\mathrm{I} \cdot \mathrm{O} \\
\mathrm{B}\end{array}$ & $\begin{array}{l}1 \cdot 5 \\
C\end{array}$ & $\begin{array}{l}0.5 \\
D\end{array}$ & $\begin{array}{l}\mathrm{I} \cdot \mathrm{O} \\
\mathrm{E}\end{array}$ & $\stackrel{\mathrm{I} \cdot 5}{\mathrm{~F}}$ \\
\hline $\begin{array}{l}\text { Modesto } \\
\text { W }\end{array}$ & $\begin{array}{l}98 \cdot I \\
99 \cdot 5\end{array}$ & $\begin{array}{l}78 \cdot 8 \\
8 \mathrm{I} \cdot 8\end{array}$ & $\begin{array}{l}80 \cdot 5 \\
86 \cdot 0\end{array}$ & $\begin{array}{l}83 \cdot 8 \\
84 \cdot 8\end{array}$ & $\begin{array}{l}76 \cdot 2 \\
76 \cdot 8\end{array}$ & $\begin{array}{l}80 \cdot 7 \\
89 \cdot 8\end{array}$ & $\begin{array}{l}89 \cdot 3 \\
89 \cdot 2\end{array}$ & $\begin{array}{l}84 \cdot 0 \\
8 \mathrm{I} \cdot 8\end{array}$ & $\begin{array}{l}85 \cdot 5 \\
84 \cdot 3\end{array}$ & $\begin{array}{l}82 \cdot 0 \\
78 \cdot 5\end{array}$ & $\begin{array}{l}82 \cdot 8 \\
78 \cdot 8\end{array}$ & $\begin{array}{l}83 \cdot 0 \\
80 \cdot 0\end{array}$ \\
\hline 17756 & $92 \cdot 0$ & $80 \cdot 0$ & $82 \cdot 8$ & $79 \cdot 7$ & $78 \cdot 0$ & $86 \cdot 5$ & $8 \mathrm{I} \cdot 8$ & $79 \cdot 2$ & $77 \cdot 0$ & $74 \cdot 5$ & $74 \cdot 7$ & $78 \cdot 3$ \\
\hline G & $99 \cdot 0$ & $84 \cdot 5$ & $9 r \cdot 2$ & $85 \cdot 5$ & $83 \cdot 0$ & $96 \cdot 2$ & $95 \cdot 2$ & $86 \cdot 8$ & $87 \cdot 3$ & $77 \cdot 8$ & $79 \cdot 5$ & $80 \cdot 7$ \\
\hline 0222 & $85 \cdot 0$ & $79 \cdot 5$ & $78 \cdot 8$ & $8 \mathrm{I} \cdot 3$ & $77 \cdot 0$ & $8 \mathrm{I} \cdot 0$ & $85 \cdot 3$ & $78 \cdot 3$ & $79 \cdot 7$ & $78 \cdot 5$ & 77.0 & $82 \cdot 3$ \\
\hline $\mathrm{z}$ & $70 \cdot 2$ & 75.0 & $74 \cdot 2$ & $64 \cdot 7$ & $66 \cdot 5$ & $65 \cdot 3$ & $75 \cdot 5$ & $72 \cdot 0$ & $73 \cdot 7$ & $66 \cdot 2$ & 65.0 & $68 \cdot 3$ \\
\hline Analysis & \multicolumn{6}{|c|}{ Significance level } & \multicolumn{6}{|c|}{ Significance level } \\
\hline $\mathrm{ABC} v \cdot \mathrm{DEF}$ & \multicolumn{6}{|c|}{$>0.005$} & \multicolumn{6}{|c|}{$>0.01$} \\
\hline A v. BC & \multicolumn{6}{|c|}{$>0.05$} & \multirow{2}{*}{\multicolumn{6}{|c|}{$>0.005$}} \\
\hline F v. DE & \multicolumn{6}{|c|}{ NS } & \multirow{2}{*}{\multicolumn{6}{|c|}{$>0.01$}} \\
\hline B v. C & \multirow{2}{*}{\multicolumn{6}{|c|}{ NS }} & & & & & & \\
\hline $\mathrm{D} v . \mathrm{E}$ & & & & & & & \multicolumn{6}{|c|}{$\begin{array}{l}\text { NS } \\
\text { NS }\end{array}$} \\
\hline $\mathrm{B} v . \mathrm{E}$ & \multicolumn{6}{|c|}{$>0.05$} & \multicolumn{6}{|c|}{$>0.025$} \\
\hline$D v . F$ & \multicolumn{6}{|c|}{ NS } & \multicolumn{6}{|c|}{$>0.005$} \\
\hline$C v \cdot F$ & \multirow{2}{*}{\multicolumn{6}{|c|}{$\begin{array}{l}>0.05 \\
>0.05\end{array}$}} & \multirow{2}{*}{\multicolumn{6}{|c|}{$\begin{array}{c}\text { NS } \\
>0.05\end{array}$}} \\
\hline Ev. F & & & & & & & & & & & & \\
\hline
\end{tabular}

Ns, Not significant.

* Four sets of comparisons, extraneous data not included. Since the error components were heterogeneous (Bartlett's chi-square test for homogeneity) each comparison was tested using its own error component. $\uparrow$ Three trials. 
Table 2. Number of replicates (out of a total of three) showing growth $(<98 \% \mathrm{Tat} 660 \mathrm{~nm})$ of six strains of Haemophilus species in TMB with $\mathrm{NaCl}$ replaced by another salt

\begin{tabular}{|c|c|c|c|c|c|c|c|c|}
\hline \multirow[b]{2}{*}{ Salt } & \multirow{2}{*}{$\begin{array}{l}\text { Time } \\
\text { (h) }\end{array}$} & \multirow{2}{*}{$\begin{array}{l}\text { Cation } \\
\text { concn }(M)\end{array}$} & \multicolumn{6}{|c|}{ Strain } \\
\hline & & & Modesto & $\mathrm{w}$ & 17756 & G & 0222 & $\mathrm{z}$ \\
\hline \multirow[t]{2}{*}{$\mathrm{NaH}_{2} \mathrm{PO}_{4}$} & 24 & $\begin{array}{l}0.085 \\
0.17\end{array}$ & $\begin{array}{l}3 \\
2\end{array}$ & $\begin{array}{l}2 \\
0\end{array}$ & $\begin{array}{l}3 \\
2\end{array}$ & $\begin{array}{l}3 \\
0\end{array}$ & $\begin{array}{l}3 \\
\text { I }\end{array}$ & $\begin{array}{l}3 \\
3\end{array}$ \\
\hline & 48 & $\begin{array}{l}0.085 \\
0.17\end{array}$ & $\begin{array}{l}3 \\
3\end{array}$ & $\begin{array}{l}3 \\
3\end{array}$ & $\begin{array}{l}3 \\
3\end{array}$ & $\begin{array}{l}3 \\
2\end{array}$ & $\begin{array}{l}3 \\
3\end{array}$ & $\begin{array}{l}3 \\
3\end{array}$ \\
\hline \multirow[t]{2}{*}{$\left.\begin{array}{l}\mathrm{KH}_{2} \mathrm{PO}_{4} \\
\mathrm{~K}_{2} \mathrm{HPO}_{4}\end{array}\right\}^{*}$} & 24 & $\begin{array}{l}0.085 \\
0.17\end{array}$ & $\begin{array}{l}0 \\
0\end{array}$ & $\begin{array}{l}0 \\
0\end{array}$ & $\begin{array}{l}0 \\
0\end{array}$ & $\begin{array}{l}0 \\
0\end{array}$ & $\begin{array}{l}0 \\
0\end{array}$ & $\begin{array}{l}\circ \\
\circ\end{array}$ \\
\hline & 48 & $\begin{array}{l}0.085 \\
0.17\end{array}$ & $\begin{array}{l}\circ \\
\circ\end{array}$ & $\begin{array}{l}0 \\
0\end{array}$ & $\begin{array}{l}\circ \\
\circ\end{array}$ & $\begin{array}{l}\circ \\
\circ\end{array}$ & $\begin{array}{l}0 \\
0\end{array}$ & $\begin{array}{l}\circ \\
\circ\end{array}$ \\
\hline \multirow[t]{2}{*}{$\mathrm{MgSO}_{4}$} & 24 & $\begin{array}{l}0.085 \\
0.17\end{array}$ & $\begin{array}{l}\circ \\
\circ\end{array}$ & $\begin{array}{l}0 \\
0\end{array}$ & $\begin{array}{l}\circ \\
\circ\end{array}$ & $\begin{array}{l}0 \\
0\end{array}$ & $\begin{array}{l}0 \\
0\end{array}$ & $\begin{array}{l}3 \\
0\end{array}$ \\
\hline & 48 & $\begin{array}{l}0.085 \\
0.17\end{array}$ & $\begin{array}{l}0 \\
0\end{array}$ & $\begin{array}{l}0 \\
0\end{array}$ & $\begin{array}{l}0 \\
0\end{array}$ & $\begin{array}{l}0 \\
0\end{array}$ & $\begin{array}{l}0 \\
0\end{array}$ & $\begin{array}{l}3 \\
0\end{array}$ \\
\hline \multirow[t]{2}{*}{$\mathrm{NaCl}$ control } & 24 & $\begin{array}{l}0.085 \\
0.17\end{array}$ & $\begin{array}{l}3 \\
3\end{array}$ & $\begin{array}{l}3 \\
3\end{array}$ & $\begin{array}{l}3 \\
3\end{array}$ & $\begin{array}{l}3 \\
3\end{array}$ & $\begin{array}{l}3 \\
3\end{array}$ & $\begin{array}{l}3 \\
3\end{array}$ \\
\hline & 48 & $\begin{array}{l}0.085 \\
0.17\end{array}$ & $\begin{array}{l}3 \\
3\end{array}$ & $\begin{array}{l}3 \\
3\end{array}$ & $\begin{array}{l}3 \\
3\end{array}$ & $\begin{array}{l}3 \\
3\end{array}$ & $\begin{array}{l}3 \\
3\end{array}$ & $\begin{array}{l}3 \\
3\end{array}$ \\
\hline
\end{tabular}

Table 3. $N A D H$ requirement for growth of six strains of Haemophilus species

$\begin{array}{lcc}\text { Strain } & \begin{array}{c}\text { Time } \\ \text { (h) }\end{array} & \begin{array}{c}\text { Optimum NAD } \\ \text { for maximum growt }\end{array} \\ \text { Modesto } & 24 & 3 \cdot 13 \\ & 48 & \leqslant \mathrm{I} \cdot 56 \\ \mathrm{~W} & 24 & \mathrm{I} 2 \cdot 5 \\ & 48 & \mathrm{I} 2 \cdot 5 \\ \mathrm{I} 7756 & 24 & \mathrm{I} 2 \cdot 5 \\ \mathrm{G} & 48 & 6 \cdot 25 \\ \mathrm{G} & 24 & 25 \\ \mathrm{O} 222 & 48 & \mathrm{I} 2 \cdot 5 \\ \mathrm{Z} & 24 & 6 \cdot 25 \\ \mathrm{Z} & 48 & \leqslant \mathrm{I} \cdot 56 \\ & 24 & \leqslant \mathrm{I} \cdot 56 \\ & 48 & \leqslant \mathrm{I} \cdot 56\end{array}$

* The growth response for each strain to an NADH concentration greater than these values was not significantly different at the $5 \%$ level of probability.

analysis of variance (two-way analysis with one observation/cell). Each mean value was compared with every other mean value using Tukey's W procedure (Steel \& Torrie, I960).

\section{RESULTS}

Effect of $\mathrm{NaCl}$ on growth. Generally growth was best in both media within the 0.5 to $\mathrm{I} \cdot 5 \% \mathrm{NaCl}$ range. Within this range the strains, with the exception of 0222 , grew better in the buffered medium (Fig. I). The detailed results with an analysis are given in Table I. 
Replacement of $\mathrm{NaCl}$ with other salts. Replacement of $\mathrm{NaCl}$ with any salt other than a sodium salt resulted in the complete absence of growth in every case, with the exception of strain $\mathrm{Z}$ and $\mathrm{MgSO}_{4}$. However, the incidence of growth at $24 \mathrm{~h}$ with $0 \cdot 17 \mathrm{M}-\mathrm{NaH}_{2} \mathrm{PO}_{4}$ was less than with $0.17 \mathrm{M}-\mathrm{NaCl}$ suggesting that the high phosphate molarity may be detrimental (Table 2).

Optimum NADH requirement. The optimum concentration of NADH for maximum growth of all strains at $24 \mathrm{~h}$ ranged from $\mathrm{I} \cdot 56$ to $25 \mu \mathrm{g} \mathrm{ml}^{-1}$ and at $48 \mathrm{~h}$ this requirement was reduced for at least five of the six strains (Table 3 ). No growth occurred in the absence of NADH.

\section{DISCUSSION}

Previously, the six strains of coryza-producing organisms used would have been regarded taxonomically as Haemophilus paragallinarum. This and a previous study (Rimler et al., 1976) have shown that although these strains require only the V factor, the other growth requirements demonstrated are compatible with descriptions found in the literature for Haemophilus gallinarum (Delaplane et al., 1938; Gregory, 1944).

The concentrations of $\mathrm{NaCl}$ required for optimum growth were between $\mathrm{I} \cdot 0$ and $\mathrm{I} \cdot 5 \%$ (w/v) confirming those reported by Gregory (1944). Delaplane et al. (1938) reported an $\mathrm{NaCl}$ optimum between $\mathrm{I} \cdot 5$ to $2.0 \%(\mathrm{w} / \mathrm{v})$; however, their method for determination of this requirement employed broth at the base of agar slopes which may partly account for the variations in the optimum $\mathrm{NaCl}$ range observed.

Inclusion of a sodium salt buffer into a broth medium provides better growth potential and apparently contributes to the sodium requirement of the organism. This contribution of sodium ions by the buffer may explain the ability of some strains to grow in $0.5 \% \mathrm{NaCl}$ at $24 \mathrm{~h}$. The decrease of this optimum range at $48 \mathrm{~h}$ for the same organism in buffer to between 0.5 to $1.0 \% \mathrm{NaCl}$ may be due to the presence of phosphate. In any event the best growth for all strains was obtained in a buffered medium containing $1.0 \% \mathrm{NaCl}$.

There is not an absolute requirement for $\mathrm{NaCl}$ in this system since it could be replaced by another sodium salt, though not by potassium or magnesium salts. Growth was less with sodium phosphate than with $\mathrm{NaCl}$, especially at the higher concentration. This may be due to the high phosphate concentration or the lack of chloride.

All six strains studied required V factor (NAD). Growth varied with different concentrations and strains. In a study of the NAD requirement of $H$. parainfluenzae, Evans, Smith \& Wicken (1974) also observed variation of the optimum levels within this species. It is interesting that the highest optimum at $24 \mathrm{~h}$ growth of the six strains studied here $\left(25 \mu \mathrm{g} \mathrm{ml}^{-1}\right)$ was the same as that noted in their study. Most apparent in our study was the lowered optimum level required for maximum growth at $48 \mathrm{~h}$; several strains only required NADH at about the minimum of $2.5 \mu \mathrm{g} \mathrm{ml}^{-1}$ reported by Page (I962). The decrease in requirement for $\mathrm{NADH}$ after $24 \mathrm{~h}$ in this case probably reflects a difference in the growth rate of the respective strain. If this is true, higher concentrations of NADH (to a certain optimum level) will produce a greater growth rate. Differences in $\mathrm{V}$ factor requirements could explain previous reports of maximum growth at $24 \mathrm{~h}$.

All strains grew better in an increased $\mathrm{CO}_{2}$ atmosphere than in an aerobic atmosphere (Rimler et al., 1976).

From our studies it would appear that the characteristic properties for differentiation of $H$. gallinarum and $H$. paragallinarum should be confined to observed $\mathrm{X}$ and $\mathrm{V}$ factor variations and should not include $\mathrm{NaCl}$ requirements.

Recent reports by Evans \& Smith (1972) and Evans et al. (1974) have emphasized the 
difficulty encountered when impure compounds are used as sources of $\mathrm{X}$ factor for Haemophilus speciation. Evans \& Smith (1972) reported that I I of $37 \mathrm{~V}$ factor-dependent strains of human origin required an additional factor present in horse blood and thus suggested a requirement for both $\mathrm{X}$ and $\mathrm{V}$ factors. This assumption was shown to be invalid when sodium oleate was used instead of blood and the resultant growth was easily characterized as $H$. parainfluenzae.

The ability of Haemophilus species to synthesize their own $\mathrm{X}$ factor does not preclude the enhancement of growth when this factor is available from an exogenous source. This rather confusing characteristic is most likely associated with the use of impure compounds which provide sufficient amounts of haemin intermediates to permit growth. Such phenomena have been documented for $H$. parainfluenzae (Evans et al., 1974) and for certain of the pasteurellae (Jordan, I952).

It was not within the scope of our current protocol to prove the need or lack of an $\mathrm{X}$ factor requirement for the $H$. gallinarum strains of Schalm \& Beach (I936) and Delaplane et al. (1938). However, such proof would relate directly to their use of horse blood or its extracts as sources of $\mathrm{X}$ factor.

Recent studies in our laboratory have shown that an oleic-albumin complex can partially replace the chicken serum requirement for the growth of our strains (Rimler, unpublished). In view of these data and the previous similar documentation, it is reasonable to challenge the absolute $\mathrm{X}$ factor requirement reported for the original strains of $H$. gallinarum.

\section{REFERENCES}

Biberstein, E. L., Mini, P. D. \& Gills, M. G. (1963). Action of Haemophilus cultures on $\delta$-aminolevulinic acid. Journal of Bacteriology 86, 814-819.

Biberstein, E. L. \& White, D. C. (1969). A proposal for the establishment of two new Haemophilus species. Journal of Medical Microbiology 2, 75-78.

Delaplane, J. P., Erwin, L. E. \& Stuart, H. O. (I934). A hemophilic bacillus as the cause of an infectious rhinitis (coryza) of fowls. Rhode Island Agricultural Experiment Station Bulletin 244, 5-I 2.

Delaplane, J. P., Erwin, L. E. \& Stuart, H. O. (1938). The effect of the X factor, of sodium chloride, and of the composition of the nutrient media upon the growth of the fowl coryza bacillus, Hemophilus gallinarum. Journal of Agricultural Research 56, 919-926.

Elliot, C. P. \& Lewis, M. R. (1934). A hemophilic bacterium as a cause of infectious coryza in the fowl. Journal of the American Veterinary Medical Association 37, 878-888.

Evans, N. M. \& SMITh, D. D. (1972). The effect of the medium and source of growth factors on the satellitism test for Haemophilus species. Journal of Medical Microbiology 5, 509-5I4.

Evans, N. M., SMith, D. D. \& Wicken, A. J. (I974). Haemin and nicotinamide adenine dinucleotide requirements of Haemophilus influenzae and $H$. parainfluenzae. Journal of Medical Microbiology 7, 359-365.

Gregory, D. W. (I944). Nutrient requirements of Hemophilus gallinarum. Americal Journal of Veterinary Research 5, 72-78.

Jordan, R. M. M. (1952). The nutrition of Pasteurella septica. I. The action of haematin. British Journal of Experimental Pathology 33, 27-35.

Nelson, J. B. (1932). Etiology of an uncomplicated coryza in the domestic fowl. Proceedings of the Society for Experimental Biology and Medicine 30, 306-307.

PAGE, L. A. (I962). Haemophilus infections of chickens. I. Characteristics of 12 Haemophilus isolates recovered from diseased chickens. American Journal of Veterinary Research 23, 85-94.

Rimler, R. B., Shotts, E. B., Brown, J. \& Davis, R. B. (I976). The effect of atmospheric conditions on the growth of Haemophilus gallinarum in a defined medium. Journal of General Microbiology 92, 405-409.

SCHALM, O. W. \& BEACH, J. R. (1936). Cultural requirements of the fowl-coryza bacillus. Journal of Bacteriology 3I, I6I-I69.

Steel, R. G. D. \& Torrie, J. H. (I960). Principles and Procedures of Statistics. New York: McGraw-Hill.

ZinnemanN, K. \& BibersteIn, E. L. (I975). Bergey's Manual of Determinative Bacteriology, 8th edn, pp. 364-367. Baltimore: Williams \& Wilkins. 